\section{TLO}

28,1

\section{2}

Received 9 March 2020 Revised 25 June 2020 13 August 2020 8 September 2020 11 September 2020 Accepted 11 September 2020

\title{
Critical realism and organizational learning
}

\author{
Louise Brøns Kringelum
} Aalborg University Business School, Aalborg University, Aalborg, Denmark, and Jacob Brix Department of Culture and Learning, Aalborg University, Aalborg, Denmark

\begin{abstract}
Purpose - This study aims to investigate the implications of applying critical realism to the study of organizational learning. It considers critical realism as an alternate theoretical science foundation to the domains of empirical realism and social constructivism that characterize most of the field of organizational learning.
\end{abstract}

Design/methodology/approach - This study adopts the approach of a philosophical/conceptual discussion. Findings - This study finds that the critical realist approach makes it possible for organizational learning researchers to apply a prescriptive change agenda. It requires researchers to study the context in which organizational learning occurs. These two features enable the researcher to propose what the world must be like for organizational learning to occur. Hence, a critical realist foundation moves organizational learning theory a step closer to its theoretical sibling, the learning organization.

Originality/value - This study reveals the potential in applying critical realism to the study of organizational learning and identifies its related strengths.

Keywords Organizational learning, Critical realism, Exploration and exploitation, Critical realist, Theory of science

Paper type Conceptual paper

\section{Introduction}

In the body of knowledge related to organizational learning, there are two clear science theoretical domains that stand out. One is based on an empirical realist tradition and the other on a social constructivist tradition (Örtenblad, 2002). The empirical realist tradition, which is recognized by the scholarly work of, for example, Argyris and Schön (1997), Argote (1999) and Huber (2004), argues that changes should be identified in the organization before it can be claimed that organizational learning has occurred. In other words, learning is evidence-based. Another important feature of this tradition is that knowledge is regarded as being codifiable (explicit), and hence, transferrable. Örtenblad (2001) calls this tradition "old organizational learning." The social constructivist tradition, which emanates from the classical work on communities of practice by Brown and Duguid (1991) and Lave and Wenger (1991), argues that learning is a context-dependent, situated process that occurs collectively between people (Elkjaer, 2004; Hernes and Irgens, 2012; Filstad, 2014). In this traditional knowledge is argued to

(C) Louise Brøns Kringelum and Jacob Brix. Published by Emerald Publishing Limited. This article is published under the Creative Commons Attribution (CC BY 4.0) licence. Anyone may reproduce, distribute, translate and create derivative works of this article (for both commercial and non-commercial purposes), subject to full attribution to the original publication and authors. legalcode 
be tacit and the nomenclature used is more often one of knowing than of knowledge. Örtenblad Critical realism (2001) calls this tradition "new organizational learning."

In this study, the science theoretical horizons of both the "old" and "new" organizational learning traditions are reconsidered and recombined, and this is done by proposing critical realism (Bhaskar, 1975) as an alternate science theoretical domain to the field. The inspiration to embark on such a radical journey stems from the increased use of critical realism in organization and management studies (Fleetwood, 2005; Fletcher, 2017; Kringelum, 2017) and this study, therefore, contributes to this tendency as it sets out to analyze and discuss the implications of applying critical realism to our field.

The study's key contributions are as follows. First, an illustrative framework for organizational learning theory is proposed to enable a scientific discussion. Second, it is argued that a critical realist approach to organizational learning implies that organizational learning researchers can include a prescriptive standpoint in their studies. Third, the critical realist perspective does offer an integrative theoretical science lens to study both process (new organizational learning) and output/outcome (old organizational learning) in conjunction, rather than each individually (Örtenblad, 2001, 2002). The second and third contributions imply that critical realism adds an element of the learning organization to organizational learning (Tsang, 1997; Örtenblad, 2002, 2019a), as the discussion in this study clarifies. An important point, however, is that critical realism is oriented toward explaining the mechanisms that cause certain outcomes to be created (Ackroyd and Karlsson, 2014) and how and why these mechanisms are triggered by the activities of organizational members in their local organizational context (Bhaskar, 1975; Argote, 2013; Krogstrup, 2016). Another important feature of critical realism is that it is not interested in inducing best practices. Such approaches are at risk of becoming epistemic fallacies because organizational learning is a complex, social phenomenon (Brix, 2019). This implies that causal logic does not necessarily deliver the same outputs and outcomes in all contexts (Bhaskar, 1975; Buch-Hansen and Nielsen, 2005; Argote, 2013; Fletcher, 2017), which is an important distinction from the empirical realist notion of organizational learning.

This work is structured as a conceptual paper. The next section, the theoretical background, briefly introduces critical realism as a theoretical science approach and provides an illustrative and generic view on organizational learning theory. Then, the following section discusses the implications of applying critical realism as a theoretical science lens to study organizational learning. The final section concludes the study.

\section{Theoretical background}

Critical realism as a theoretical science approach

Founded in the seminal writings of Roy Bhaskar in the 1970s (Bhaskar, 1975, 1979), critical realism is a philosophy of science that has often been referenced in organization and management studies (McAvoy and Butler, 2018; Frederiksen and Kringelum, 2020). Critical realism represents an alternate to both positivist and constructivist perspectives with an inherent aim of not just explaining the world but also changing it (Alvesson and Sköldberg, 2009). Therefore, as a philosophy of science, critical realism embraces both analytical descriptive and prescriptive agendas. In contrast to classic empiricism and transcendental idealism, critical realism represents a transcendental realism that emphasizes the structures and mechanisms that generate the phenomenon being studied. The objects that can be studied can be regarded as:

[... . neither phenomena (empiricism) nor human constructs imposed upon phenomena (idealism), but real structures which endure and operate independently of our knowledge, our experience and the conditions which allow us access to them. (Bhaskar, 1975, p. 25) 
TLO

28,1

Therefore, a premise of critical realism is that our knowledge of the world and the nature of the world are not identical (Bhaskar, 1975, 1998). Rather, through rigorous research, researchers can study and add to the knowledge of the world in an attempt to analyze organizational practices and provide suggestions for how these practices can be improved to generate better outputs and outcomes (Buch-Hansen and Nielsen, 2005; Ackroyd and Karlsson, 2014). Thus, not implying that critical realism is an inherently managerial paradigm but rather that it provides the potential for middle-range theorizing (Bygstad et al., 2016) in exploring mechanisms to uncover new, applicable approaches, for example, for organizational learning. To do so, critical realism offers a stratified ontology that represents a frame for acknowledging the varied layers of reality through the empirical, the actual and the real domain (Bhaskar, 1975).

\section{The ontology and epistemology of critical realism}

The stratified ontology of critical realism made up of the empirical, the actual and the real domains distinguish between the transitive knowledge of reality and the intransitive reality that exists.

The empirical domain is made up of incidents that researchers can observe, participate in or experience in the empirical world (Bhaskar, 1975). The observations identified at the empirical level and their conjunction with experienced events become transitive objects of knowledge that represent the interpretation of the researcher (Buch-Hansen and Nielsen, 2005). The actual domain represents events that are distinct from those observed empirically and can include unobserved events and phenomena (Bhaskar, 1975). The central aspect of the stratified ontology of critical realism is the real domain. This domain is unobservable. The point is that the real domain consists of structures and mechanisms representing causal tendencies that might or might not be activated, implying that causality is not linear in critical realism (Bhaskar, 1975; Mingers and Standing, 2017). In this regard, mechanisms are simply "a way of acting of a thing" (Bhaskar, 1975, p. 51) but mechanisms might not be reduced to the events that they generate (Fletcher, 2017). Hence, mechanisms are not directly observable but are derived through interpretation based on the researcher's intuition and frame of reference (Ackroyd and Karlsson, 2014). Thus, the researcher plays a central role in securing analytical validity when developing, analyzing and interpreting knowledge about the world (BuchHansen and Nielsen, 2005; Fletcher, 2017; Frederiksen and Kringelum, 2020), thereby reflecting the subjective epistemology of the paradigm. This interpretive role of the researcher presupposes transparency and rigor to ensure that the research process is not led astray by epistemic fallacies whereby the nature of the world is reduced to what can be known empirically (Bhaskar, 1998). When identifying causal mechanisms, the researcher can uncover formative processes in the context that influence the outcomes (Ackroyd and Karlsson, 2014) through which propositions for change can be developed (Fletcher, 2017). This analytical work cannot be undertaken without considering all three domains (Bhaskar, 1975).

\section{The events of entities as the research object}

The research object of critical realism is the events of entities (Easton, 2010). Events of entities represent excerpts of the field that can be used to uncover the phenomenon being studied. By exploring events of entities, researchers aim to explain why the world may be unfolding as it is through causal analysis. For this reason, the non-occurrence of an expected event can be as interesting as the occurrence of an event (Kringelum, 2017). The concept of entities covers all objects "tangible and intangible, social or physical, dormant or active" (Easton, 2010, p. 125), and therefore, they must be defined. When defining objects, researchers need to delineate (the often) multiple entities actively to acknowledge the 
complexity of the nature of the world under study in terms of both internal and external relationships between entities (Sayer, 2000). An entity makes a difference in its own right but is always more than the sum of its parts (Fleetwood, 2005). The relationship between entities reflects their causal powers, that is, the way an entity can cause something to occur in other entities. The liability of entities represents the way in which an entity can be affected by other entities (Sayer, 2000). According to Elder-Vass (2010), the metaphor of a laminated system helps to delineate the relationships between entities. As an entity, an organization can be divided into various sub-entities such as departments, teams, managers and employees. These sub-entities represent different layers of an organization (Elder-Vass, 2010), which enable researchers to regard the roles of the parts and how they may affect the causal impacts at other levels in the organization.

\section{Prescribing changes via retroduction}

The attempt to explain the world and the events observed through generative mechanisms that exist in the real domain is called the process of retroduction (O'Mahoney and Vincent, 2014). The aim of retroduction is to explain what the world must be like to trigger the generative mechanism acting in the real domain and to generate an event in the empirical or actual domain (Edwards et al., 2014) [1]. The retroduction process can be locally oriented toward the local context that can be improved. Based on analytical generalizability, retroduction can also be directed toward more general aspects of how the context has been (and hence, has to be) to trigger a generative mechanism that can create the outcomes it promises in other settings (Mingers and Standing, 2017). As a result, critical realism calls for theoretical pluralism, as various mechanisms are involved in the generation of an event and they are not reducible to only one theory. Therefore, critical realism has the potential to function as a metatheory (Frederiksen and Kringelum, 2020) that can enable a researcher to grasp the complexity of the world when she or he applies various theoretical lenses (Danermark, 2019).

Creating an analytical framework for organizational learning theory

To enable a science discussion, an illustrative program theory is set (Chen, 2015) for the field of organizational learning (Figure 1). Inspired by Brix et al. (2020), the illustrative program theory acts as a simplified framework that distills key attributes of organizational learning theory into the following six analyzable sub-themes.

(1) What is the problem that organizational learning theory can provide answers to?

(2) What are the expected outputs of organizational learning?

(3) What are the expected outcomes of organizational learning?

(4) What mechanisms represent the foundation of organizational learning?

(5) What contextual variables can affect local implementation?

Examples of implementation strategies and the nature of these local activities.

What problem does organizational learning theory aim to understand and solve?

The literature stresses the potential of organizational learning to create improvement, renewal, strategic renewal and innovation in established organizations (March, 1991; Crossan et al., 1999; Örtenblad, 2002; Argote and Miron-Spektor, 2011; Nielsen et al., 2018). Because of the complexity related to such development-oriented problems, Lyles (2014) 


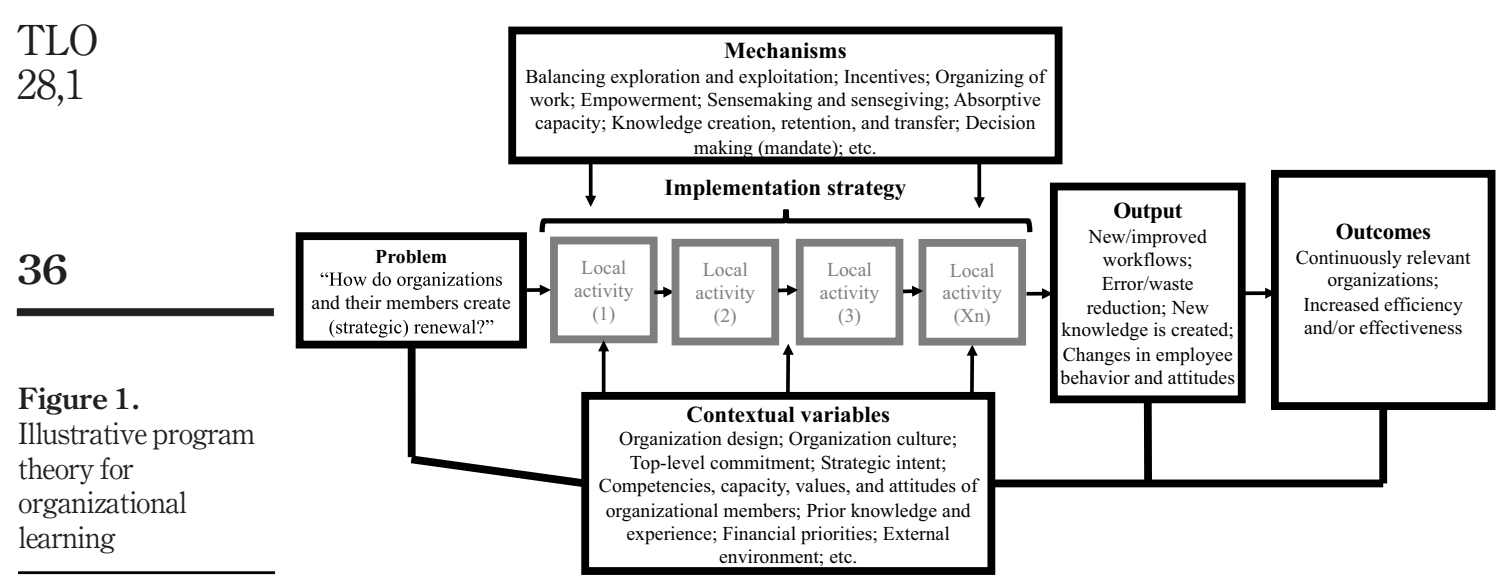

stresses that organizational learning has an important role to play in responding to wicked problems.

\section{Outputs}

Known outputs from the organizational learning literature include, for example, improved workflows, reduction of material waste from industrial production and time wasted on nonvalue-adding activities (Fiol and Lyles, 1985; March, 1991; Argote, 1999, 2013). Other types of outputs are new knowledge (Lyles, 2014; Brix, 2017; Nielsen et al., 2018) and changes in employee behavior and attitudes (Argyris and Schön, 1997; Brix, 2020). The multi-level model of organizational learning introduced by Crossan et al. (1999) enables researchers to study how, when and where learning occurs at the individual, the group/team and the organizational levels of analysis (see also Argote, 2013; Morland et al., 2019). Another benefit of using a multi-level lens to study organizational learning is that it enables researchers to study what (and hence, the knowledge-related outputs) are created via the learning processes on the different levels (Brix, 2017).

\section{Outcomes}

Becoming and remaining continuously relevant is an outcome often mentioned in the organizational learning literature (March, 1991; Crossan et al., 1999; Huber, 2004). Other outcomes mentioned are the creation of increased efficiency and/or effectiveness in processes and better customer or user satisfaction with products and services (March, 1991; Beer et al., 2005; Burton et al., 2015).

\section{Mechanisms}

The ability to balance exploration and exploitation is recognized as a mechanism that supports the creation of a continuously relevant organization (March, 1991; Crossan et al., 1999; Lyles, 2014; Brix, 2019). In addition, the manner in which incentives are given influences on how organizational members act and react in different situations (Thuy Pham and Swierczek, 2006; Burton et al., 2015). Moreover, organization of work, employee empowerment and communication (e.g. sensemaking and sense giving) affect the outcomes of organizational learning processes (Argote, 1999; Huber, 2004; Morland et al., 2019). Absorptive capacity (Cohen and Levinthal, 1990) is another important mechanism that can 
trigger organizational learning outcomes (Volberda et al., 2010; Argote, 2013). Furthermore, knowledge creation, retention and transfer (Argote, 1999, 2013) enable improvement and (strategic) renewal of organizations. Finally, the decision-making mandate and how decisions are made can affect the outputs and outcomes of organizational learning processes (Weick, 1996; Hernes and Irgens, 2012; Brix, 2017).

\section{Contextual variables}

Argote concludes that "a 'conditions-seeking' approach that identifies the conditions under Critical realism which particular variables have desired effects on organizational outcomes is needed" (Argote, 1999, p. 202). She stresses that "the best approach to measuring organizational learning depends on the research question and empirical context" (Argote, 2013, p. 32). Although the importance of the context for learning and contextual variables are placed in the background in the organizational learning literature (Easterby-Smith and Lyles, 2011), recent studies establish that variables from the organization design literature, in particular, can affect the output and outcomes of organizational learning. These are, for example, workflows, structure and information processes (Argote and Miron-Spektor, 2011; Burton et al., 2015). In addition, top-level commitment, financial priorities and strategic intent are important contextual variables that can affect organizational learning processes (Beer $e t$ al., 2005; Lyles, 2014; Brix, 2020). Bapuji and Crossan (2004), Elkjaer (2004) and Lauer and Wilkesmann (2017) emphasize the importance of a learning-oriented organizational culture as opposed to a failure culture. Moreover, prior knowledge, competencies, capacity and values and attitudes of organizational members are found to play a key role in enabling organizational learning (Elkjaer, 2004; Brix, 2020). Finally, the external environment is recognized as a highly influential variable that can affect the organization in general, and therefore, also the demand for organizational learning (Huber, 2004; Morland et al., 2019). Hence, the contextual variables that can affect organizational learning processes are locally determined and context-dependent (Argote, 2013).

\section{Implementation strategy}

A key point to notice is that when the mechanisms such as those listed in this section, are translated into local activities as part of an implementation strategy in an organizational context, then the events and activities might or might not trigger the outcomes related to the mechanisms (Krogstrup, 2016). In this regard, there is no linear cause-effect relationship between the implementation strategy and the outcomes (Chen, 2015). The argument is that organizational learning is a complex, social phenomenon (Brix, 2019) used to respond to wicked problems (Lyles, 2014); hence, there is no guarantee that the same output will occur when applying the same process in different organizations (Argote, 2013; Lyles, 2014; Krogstrup, 2016). Therefore, the logic is that if the implementation strategy is appropriate and the contextual variables facilitate the implementation strategy to be fulfilled, then the mechanisms have the potential to trigger the expected outcomes (Chen, 2015; Krogstrup, 2016). Therefore, the concrete local events and activities that organizations and their members perform to become or remain continuously relevant as part of the implementation strategy could differ among organizations yet still trigger the same outcomes (Elkjaer, 2004; Argote, 2013; Krogstrup, 2016; Brix et al., 2020). To support this argument, some works such as that of Huber (1991), establish that there "are numerous and varied" processes and subprocesses related to creating knowledge that can be used to induce change (Huber, 1991, p. 107). In line with this, Bapuji and Crossan (2004) state that many different organizational learning concepts have been used to: "explain various organizational phenomena such as performance, strategic alliances, innovation, market orientation and technology adoption" 
TLO

28,1

(Bapuji and Crossan, 2004, p. 400). In addition, the organizational learning literature has numerous examples of different important types of implementation strategies. There are many examples, some of which include formal or informal communities of practice (Brown and Duguid, 1991; Filstad, 2014), total quality management (Hackman and Wageman, 1995) and processes of innovation and strategic change (Beer et al., 2005; Nielsen et al., 2018). The point, with reference to Figure 1, is that if the implementation strategy operationalized by an organization seeks to solve the problem of creating improvement or (strategic) renewal and if the output and outcome ambitions correspond to (some of) those in Figure 1, then the local activities that take place can be labeled as "organizational learning."

\section{Discussion and implications}

Organizational learning as a research object in critical realism

To define organizational learning as a research object in critical realism, the different entities constituting this object have to be operationalized (Easton, 2010). As noted earlier, entities can be, for example, departments, teams or individuals (Easton, 2010; Argote, 2013; Morland et al., 2019). Entities can also be local events and activities that are carried out for improvement or (strategic) renewal (Elkjaer, 2004). To operationalize organizational learning as a research object the components of Figure 1 are categorized as follows into the empirical, the actual and the real domains.

\section{Transitive and intransitive elements of organizational learning}

The components implementation strategy, contextual variables and the outputs and outcomes from Figure 1 can be transitively observed in the empirical domain, but even if not observed, they exist in the actual domain. This double-categorization is based on the logic that researchers may be able to study full implementation strategies as participant observers, implying that the entire process is experienced in the empirical domain (Kristiansen and Krogstrup, 2016). It might also be the case that researchers do not obtain full access to such implementation strategies. In that event, these activities would occur in the actual domain, in which the researcher cannot observe them (Bhaskar, 1975). Researchers can then access the actual domain through various means of data collection such as interviewing (Fletcher, 2017).

The mechanisms illustrated in Figure 1 are placed in the real domain, which implies that they are intransitive and cannot be observed (Bhaskar, 1975). The point is that the intransitive mechanisms related to organizational learning can be the same regardless of the size, type or age of an organization. The argument is that it is the translation of these mechanisms into local activities in an organizational context that can trigger the outcomes (Bygstad et al., 2016; Mingers and Standing, 2017; Brix, 2020). This argument corresponds to Huber's (1991) reflection that there are multiple, varied processes to create organizational learning and Argote's (2013) conclusion that similar organizations demonstrate different degrees of performance when working toward the same goal.

\section{Organizational learning as a multi-level and layered phenomenon}

It is argued, that the three domains from the stratified ontology of critical realism (Bhaskar, 1975) and its view of entities in a laminated system (Elder-Vass, 2010) can be used to strengthen the study of organizational learning on multiple levels (Crossan et al., 1999; Nielsen et al., 2018; Morland et al., 2019). From the critical realist viewpoint, it is necessary to undertake a systematic analysis of data related to both content and process on multiple levels of analysis and to reflect on data accessible in the empirical domain and the actual domain. Therefore, critical realism paves the way for researchers to unite perspectives from old and new 
organizational learning (Örtenblad, 2001) because lenses from both theoretical domains in the organizational learning field become necessary. From the multi-level view, the logic is that researchers can study how knowledge is created, for example, at a group/team level, before it potentially becomes institutionalized at an organizational level - a process that would depend on the causal powers and liabilities related to the entities (Sayer, 2000; Brix, 2017, 2020; Morland et al., 2019). In this way, a valuable, temporal perspective on learning processes can emerge.

Temporal perspectives on the emergence of outputs and outcomes

The dimension of time is central in studies of critical realism (Fleetwood, 2005). Thus, when studying organizational learning, the time lag between implementation strategies, outputs and outcomes must be considered (Brix, 2017, 2020). As emphasized by Elder-Vass (2010), the laminated system of entities and events entails that emergence occurs at various levels within the system under study. Therefore, researchers must acknowledge the existence of both synchronic and diachronic emergence (Elder-Vass, 2010). A point is, that much organizational learning research focuses on synchronic emergence, which represents the relationships between the properties of a whole (e.g. an organization) and its parts (e.g. individuals or teams) at a specific moment in time (Elkjaer, 2004; Argote, 2013). Nevertheless, from a critical realist perspective, organizational learning cannot be limited to one specific point in time, as structures and actors continuously affect each other. For this reason, aspects of diachronic emergence (Archer, 1995) must be introduced to emphasize how the historicity and preceding structures of an organization affect the temporal development and changing properties over time (Hernes and Irgens, 2012; Brix, 2017).

The need for dual focus: bringing organizational learning closer to the learning organization Applying critical realism to empirical studies of organizational learning implies that researchers need to dedicate attention to understand local contextual variables because these can affect the learning processes that take place (Buch-Hansen and Nielsen, 2005; O'Mahoney and Vincent, 2014). For example, when relying on a case study as a research strategy, it is important that researchers report on (to the extent it is possible) the key contextual variables such as organizational design, strategic orientation and topmanagement commitment of the organization (Figure 1) (Fletcher, 2017; Frederiksen and Kringelum, 2020). This is important not only as background information but as fundamental knowledge relevant for how the organizational context can have influenced the creation of certain outputs and outcomes (Bygstad et al., 2016; Kringelum, 2017; McAvoy and Butler, 2018). A key implication is that focus has to be aimed less strongly at the actual processes and initiatives that occur in organizations (implementation strategies) and instead should emphasize the nature of the contextual variables that influence these processes and, if possible, the outputs and outcomes of these processes (Argote, 2013; Brix, 2020). This implies, that a critical realist approach to organizational learning may draw the literature closer to its theoretical sibling: the learning organization. This claim might seem overgeneralized because perspectives on and definitions of the learning organization are, like those in the field of organizational learning, multiple and varied (Garratt, 1987; Senge, 1990; Burgoyne et al., 1994; Jørgensen et al., 2019). One argument in support of this claim is based on the change agenda in critical realism: when the change agenda from critical realism (Alvesson and Sköldberg, 2009) meets organizational learning theory, it invites a prescriptive orientation to the literature better known in research on the learning organization (Tsang, 1997; Easterby-Smith and Lyles, 2011; Fletcher, 2017; Örtenblad, 2018). This change agenda is explained in the next subsection. Another argument is based on 
TLO

28,1

the strong contextual, structural and climate-oriented focus that represents key elements in the literature on the learning organization (Lam, 2019; Örtenblad, 2019b). In other words, the critical realist approach to organizational learning requires researchers to reveal the conditions that support organizations in becoming learning entities (Nguyen et al., 2019), not only the implementation strategies and outputs/outcomes (Argote, 2013). Hence, the dual focus on organizational learning is important from a critical realist perspective, as if such knowledge were not reflected on or documented, it would be difficult to answer the question "how should the organizational context be to trigger a given mechanism of organizational learning?"

\section{Toward a change agenda}

As mentioned in the theoretical background section, the aim of critical realism is not only to explain but also to change the world (Alvesson and Sköldberg, 2009). Therefore, it can be argued that critical realism, founded in the tradition of retroductive reasoning, enables researchers to identify how the organizational context has to be to develop the foundation for creating improvement or (strategic) renewal (Huber, 2004; Argote and Miron-Spektor, 2011). To create such a change agenda, researchers have to perform the following steps. First, identify the mechanisms related to organizational learning that can be translated into local implementation strategies, and hence, perform an ontological deep dive for the analysis of such local activities. Second, investigate the multiple variables that are at play in the local context (Buch-Hansen and Nielsen, 2005; Argote, 2013; Fletcher, 2017; Kringelum, 2017). Third, identify the links between the contextual variables and the generative mechanisms, which both can affect how processes of organizational learning are operationalized empirically to create the expected outcomes such as continuous relevancy (March, 1991; Huber, 2004; Argote and Miron-Spektor, 2011; O’Mahoney and Vincent, 2014). However, careful consideration is required: both structures and actors affect the local activities of organizational learning and they must be regarded as two different elements.

Agents and structures are different kinds of "things" and cannot be generalized from one to the other and, moreover, they cannot be related dialectically since they do not constitute two moments of the same process (Bhaskar, 1979, p. 42).

Thus, from the critical realist perspective, research on organizational learning should acknowledge this analytical dualism and distinguish between structures and actors because both affect the outcomes (Elkjaer, 2004; Argote, 2013). Following this line of reasoning, it is argued that critical realism enables researchers to study organizational learning as processes, outputs and outcomes that exist due to a complex interplay between structure and agency on multiple levels (Crossan et al., 1999; Brix, 2017, 2020; Nielsen et al., 2018). Therefore, an important implication of applying critical realism to the study of organizational learning is that suggestions for best practices (implementation strategies) would not make sense - it, hence, represents a contradictory view compared to the empirical realist tradition (Örtenblad, 2001; Huber, 2004; Argote, 2013). This leads to an interesting dilemma because mainstream management literature has turned toward an evidence-based view on prescriptive practices as a golden standard (Kringelum, 2017; Brix et al., 2020), where the focus is on implementing generic prescriptions that promise certain outputs and outcomes (Hood and Dixon, 2015). The argument is that best practices and other managerial recipes from a critical realist view represent epistemic fallacies whereby the nature of the world is reduced to what can be known empirically (Mingers and Standing, 2017; McAvoy and Butler, 2018). Instead, the focus should be on realizing the potential that is promised by such prescriptions by identifying the generative mechanisms that are at play and then translate these into value-creating, 
contextualized practices (Bhaskar, 1975; Bygstad et al., 2016). Hence, critical realism requires that managers and employees redirect focus from implementation toward realization when striving to create improvement and/or (strategic) renewal (Argote, 2013). Adaptations would be required, not only adoptions (Krogstrup and Brix, 2019). This is an important theme when it comes to reflecting on the generalizability of research results stemming from empirical studies of organizational learning.

\section{Conclusion}

This study presented an overview of critical realism as an alternate theoretical science approach to studying organizational learning (Fleetwood, 2005; Fletcher, 2017; McAvoy and Butler, 2018). The study's first contribution is that it develops a generic program theory for organizational learning research, illustrated in Figure 1 (Chen, 2015; Brix et al., 2020). The conceptualization of Figure 1 integrates the old organizational learning domain (based on an empirical realist tradition) and the new organizational learning domain (based on a social constructivist tradition) (Örtenblad, 2001, 2002, 2018). Figure 1 and the related discussion were used to enable a theoretical science discussion of organizational learning from the critical realist perspective - adding new ontological depth to the field (Bhaskar, 1975, 1998; O'Mahoney and Vincent, 2014; Fletcher, 2017).

The study argued that a critical realist approach to organizational learning should focus on:

- outputs and outcomes, as in old organizational learning (Huber, 1991; Argyris and Schön, 1997; Argote, 1999);

- processes and activities, as in new organizational learning (Weick, 1996; Elkjaer, 2004; Hernes and Irgens, 2012); and

- contextual variables and how these variables influence the learning processes (Easton, 2010; Edwards et al., 2014; Bygstad et al., 2016; Fletcher, 2017; Brix, 2020).

Based on this tri-partite focus on processes, outputs and outcomes and also contextual variables, critical realism adds to organizational learning research the requirement to explain via retroduction how a given organizational context should be to generate desired learning outcomes (Bhaskar, 1975; Bygstad et al., 2016; Kringelum, 2017).

The implication of the theoretical science discussion is that empirical studies of organizational learning from a critical realist perspective move the field a step closer to its theoretical sibling, the learning organization. This argument is informed by the following two logics. The first logic is based on critical realism's active change agenda (Alvesson and Sköldberg, 2009), which implies that researchers can take a prescriptive standpoint to their study of organizational learning. This prescriptive nature is traditionally better known from studies of the learning organization (Tsang, 1997; Nguyen et al., 2019; Örtenblad 2019a). The second logic is that a critical realist approach to organizational learning requires researchers to focus also on the contextual variables that influence the desired outcomes of organizational learning taking place in a local, organizational context (Argote, 2013; Brix, 2017; Nguyen et al., 2019; Ortenblad, 2019a). This focus on how the organizational context should be to promote learning is also a key characteristic of studies of the learning organization (Lam, 2019; Nguyen et al., 2019; Örtenblad, 2019b).

In summary, a critical realist approach to organizational learning as framed in this study requires that researchers identify the mechanisms translated into implementation strategies in a local, organizational setting. This approach also requires researchers to prescribe how the local contextual variables should be to 
support implementation strategies when the intention is to create improvement and/or (strategic) renewal, so that the organization can remain relevant continuously (Bhaskar, 1975; Crossan et al., 1999; Huber, 2004; Fletcher, 2017).

\section{Note}

1. Bhaskar $(1975$, p. 125) explains a four-step approach to operationalize the retroduction process.

\section{References}

Ackroyd, S. and Karlsson, J.C. (2014), "Critical realism, research techniques, and research design”, in Edwards, P.K., O'Mahoney, J. and Vincent, S. (Eds), Studying Organizations Using Critical Realism, Oxford University Press, Oxford, pp. 21-45.

Alvesson, M. and Sköldberg, K. (2009), Reflexive Methodology: New Vistas for Qualitative Research, SAGE Publications, London.

Archer, M.S. (1995), Realist Social Theory: The Morphogenetic Approach, Cambridge University Press, Cambridge.

Argote, L. (1999), Organizational Learning: Creating, Retaining and Transferring Knowledge, Springer Science and Business Media, New York, NY.

Argote, L. (2013), Organizational Learning: Creating, Retaining and Transferring Knowledge, 2nd ed., Springer Science and Business Media, New York, NY.

Argote, L. and Miron-Spektor, E. (2011), "Organizational learning: from experience to knowledge", Organization Science, Vol. 22 No. 5, pp. 1123-1137.

Argyris, C. and Schön, D.A. (1997), Organizational Learning: A Theory of Action Perspective, AddisonWesley, MA.

Bapuji, H. and Crossan, M. (2004), "From questions to answers: reviewing organizational learning research", Management Learning, Vol. 35 No. 4, pp. 397-417.

Beer, M., Voelpel, S.C., Leibold, M. and Tekie, E.B. (2005), "Strategic management as organizational learning: developing fit and alignment through a disciplined process", Long Range Planning, Vol. 38 No. 5, pp. 445-465.

Bhaskar, R. (1975), A Realist Theory of Science, Leeds Books, Leeds.

Bhaskar, R. (1979), The Possibility of Naturalism, Routledge, London.

Bhaskar, R. (1998), "Philosophy and scientific realism”, in Archer, M., Bhaskar, R., Collier, A., Lawson, T. and Norrie, A. (Eds), Critical Realism: Essential Readings, Routledge, London, pp. 16-47.

Brix, J, (2020), "Building capacity for sustainable innovation: a field study of the transition from exploitation to exploration and back again”, Journal of Cleaner Production, Vol. 268, pp. 1-12, doi: $10.1016 /$ j.jclepro.2020.122381.

Brix, J. (2017), "Exploring knowledge creation processes as a source of organizational learning: a longitudinal case study of a public innovation project", Scandinavian Journal of Management, Vol. 33 No. 2, pp. 113-127.

Brix, J. (2019), "Ambidexterity and organizational learning: revisiting and reconnecting the literatures", The Learning Organization, Vol. 26 No. 4, pp. 337-351.

Brix, J., Krogstrup, H.K. and Mortensen, N.M. (2020), "Evaluating the outcomes of co-production in local government", Local Government Studies, Vol. 46 No. 2, pp. 169-185.

Brown, J.S. and Duguid, P. (1991), "Organizational learning and communities-of-practice: toward a unified view of working, learning, and innovation”, Organization Science, Vol. 2 No. 1, pp. 40-57.

Buch-Hansen, H. and Nielsen, P. (2005), Kritisk Realisme, Roskilde Universitetsforlag, Roskilde, Danmark. 
Burgoyne, J., Pedler, M. and Boydell, T. (1994), Towards the Learning Company: Concepts and Practices, Critical realism McGraw-Hill, London.

Burton, R.M., Obel, B. and Håkonsson, D.D. (2015), Organizational Design: A Step-by-Step Approach, Cambridge University Press, Cambridge.

Bygstad, B., Munkvold, B.E. and Volkoff, O. (2016), "Identifying generative mechanisms through affordances: a framework for critical realist data analysis", Journal of Information Technology, Vol. 31 No. 1, pp. 83-96.

Chen, H.T. (2015), Practical Program Evaluation: Theory-Driven Evaluation and the Integrated Evaluation Perspective, 2nd ed., SAGE Publications, London.

Cohen, W.M. and Levinthal, D.A. (1990), "Absorptive capacity: a new perspective on learning and innovation”, Administrative Science Quarterly, Vol. 35 No. 1, pp. 128-152.

Crossan, M.M., Lane, H.W. and White, R.E. (1999), "An organizational learning framework: from intuition to institution", Academy of Management Review, Vol. 24 No. 3, pp. 522-537.

Danermark, B. (2019), "Applied interdisciplinary research - a critical realist perspective", Journal of Critical Realism, Vol. 18 No. 4, pp. 368-382.

Easterby-Smith, M. and Lyles, M.A. (2011), Handbook of Organizational Learning and Knowledge Management, 2nd ed., Wiley, West Sussex.

Easton, G. (2010), "Critical realism in case study research", Industrial Marketing Management, Vol. 39 No. 1, pp. 118-128.

Edwards, P.K., O'Mahoney, J. and Vincent, S. (2014), Studying Organizations Using Critical Realism - A Practical Guide, Oxford University Press, Oxford.

Elder-Vass, D. (2010), The Causal Power of Social Structures: Emergence, Structure and Agency, Cambridge University Press, Cambridge.

Elkjaer, B. (2004), "Organizational learning: the 'third way", Management Learning, Vol. 35 No. 4, pp. 419-434.

Filstad, C. (2014), "Learning and knowledge as interrelations between CoPs and NoPs", The Learning Organization, Vol. 21 No. 2, pp. 70-82.

Fiol, C.M. and Lyles, M.A. (1985), "Organizational learning”, Academy of Management Review, Vol. 10 No. 4, pp. 803-813.

Fleetwood, S. (2005), "Ontology in organization and management studies: a critical realist perspective", Organization, Vol. 12 No. 2, pp. 197-222.

Fletcher, A.J. (2017), "Applying critical realism in qualitative research: methodology meets method", International Journal of Social Research Methodology, Vol. 20 No. 2, pp. 181-194.

Frederiksen, D.J. and Kringelum, L.B. (2020), "Five potentials for critical realism in management and organization studies", working paper, Aalborg University Business School, Aalborg University, Aalborg, Denmark.

Garratt, B. (1987), The Learning Organization, Fontana Paperbacks, London.

Hackman, J.R. and Wageman, R. (1995), "Total quality management: empirical, conceptual, and practical issues", Administrative Science Quarterly, Vol. 40 No. 2, pp. 309-342.

Hernes, T. and Irgens, E.J. (2012), "Keeping things mindfully on track: organizational learning under continuity", Management Learning, Vol. 44 No. 3, pp. 253-266.

Hood, C. and Dixon, R. (2015), A Government That Worked Better and Cost Less?: Evaluating Three Decades of Reform and Change in UK Central Government, Oxford University Press, Oxford.

Huber, G.P. (1991), "Organizational learning: the contributing processes and the literatures", Organization Science, Vol. 2 No. 1, pp. 88-115.

Huber, G.P. (2004), The Necessary Nature of Future Firms: Attributes of Survivors in a Changing World, SAGE Publications, London. 
Jørgensen, K.M., Hsu, S.-W. and Hersted, L. (2019), "The learning organization: critical analysis and future directions", in Örtenblad, A. (Ed.), The Oxford Handbook of the Learning Organization, Oxford University Press, Oxford, pp. 445-457.

Kringelum, L.B. (2017), "Transcending organizational boundaries", PhD thesis, Aalborg University Press, Aalborg, Denmark.

Kristiansen, S. and Krogstrup, H.K. (2016), Deltagende Observation: Introduktion Til en Samfundsvidenskabelig Metode, 2. udgave, Hans Reitzels Forlag, København.

Krogstrup, H.K. (2016), Evalueringsmodeller, Hans Reitzels Forlag, København.

Krogstrup, H.K. and Brix, J. (2019), Co-Produktion i Den Offentlige Sektor: Brugerinvolvering $i$ Kvalitetsudvikling, Hans Reitzels Forlag, København.

Lam, A. (2019), “Ambidextrous learning organizations”, in Örtenblad, A. (Ed.), The Oxford Handbook of the Learning Organization, Oxford University Press, Oxford, pp. 163-180.

Lauer, S. and Wilkesmann, U. (2017), "The governance of organizational learning: empirical evidence from best-practice universities in Germany", The Learning Organization, Vol. 24 No. 5, pp. 266-277.

Lave, J. and Wenger, E. (1991), Situated Learning: Legitimate Peripheral Participation, Cambridge University Press, Cambridge.

Lyles, M.A. (2014), “Organizational learning, knowledge creation, problem formulation and innovation in messy problems", European Management Journal, Vol. 32 No. 1, pp. 132-136.

McAvoy, J. and Butler, T. (2018), “A critical realist method for applied business research”, Journal of Critical Realism, Vol. 17 No. 2, pp. 160-175.

March, J.G. (1991), "Exploration and exploitation in organizational learning", Organization Science, Vol. 2 No. 1, pp. 71-87.

Mingers, J. and Standing, C. (2017), "Why things happen - developing the critical realist view of causal mechanisms", Information and Organization, Vol. 27 No. 3, pp. 171-189.

Morland, K.V., Breslin, D. and Stevenson, F. (2019), "Development of a multi-level learning framework", The Learning Organization, Vol. 26 No. 1, pp. 78-96.

Nguyen, N., Hansen, J.Ø. and Jensen, A. (2019), "How best to study the learning organization", in Ortenblad, A. (Ed.), The Oxford Handbook of the Learning Organization, Oxford University Press, Oxford, pp. 348-359.

Nielsen, J.A., Mathiassen, L. and Hansen, A.M. (2018), "Exploration and exploitation in organizational learning: a critical application of the 4i model", British Journal of Management, Vol. 29 No. 4, pp. 835-850.

O'Mahoney, J. and Vincent, S. (Eds) (2014), "Critical realism as an empirical project", in Edwards, P.K., O'Mahoney, J. and Vincent, S. (Eds), Studying Organizations Using Critical Realism - A Practical Guide, Oxford University Press, Oxford, pp. 1-20.

Örtenblad, A. (2001), "On differences between organizational learning and learning organization”, The Learning Organization, Vol. 8 No. 3, pp. 125-133.

Örtenblad, A. (2002), "Organizational learning: a radical perspective”, International Journal of Management Reviews, Vol. 4 No. 1, pp. 71-85.

Örtenblad, A. (2018), "What does "learning organization" mean?", The Learning Organization, Vol. 25 No. 3, pp. 150-158.

Örtenblad, A. (2019a), "Contextualizing the learning organization: towards differentiated standards", The Oxford Handbook of the Learning Organization, Oxford University Press, Oxford, pp. 379-390.

Örtenblad, A. (2019b), "Suggestions for future research on the learning organization", The Oxford Handbook of the Learning Organization, Oxford University Press, Oxford, pp. 477-486.

Sayer, A. (2000), Realism and Social Science, SAGE, London. 
Senge, P. (1990), The Fifth Discipline: The Art and Practice of the Learning Organization, Doubleday, Critical realism New York, NY.

Thuy Pham, N. and Swierczek, F.W. (2006), "Facilitators of organizational learning in design", The Learning Organization, Vol. 13 No. 2, pp. 186-201.

Tsang, E.W. (1997), "Organizational learning and the learning organization: a dichotomy between descriptive and prescriptive research", Human Relations, Vol. 50 No. 1, pp. 73-89.

Volberda, H.W., Foss, N.J. and Lyles, M.A. (2010), "Perspective - absorbing the concept of absorptive capacity: how to realize its potential in the organization field", Organization Science, Vol. 21 No. 4, pp. 931-951.

Weick, K.E. (1996), "The role of renewal in organizational learning”, International Journal of Technology Management, Vol. 11 Nos 7/8, pp. 738-746.

\section{Corresponding author}

Jacob Brix can be contacted at: jacobb@hum.aau.dk

For instructions on how to order reprints of this article, please visit our website: 